М. В. Ковба, В. Б. Рій

Національна академія Сухопутних військ імені гетьмана Петра Сагайдачного, Львів, Україна

\title{
ОБГРУНТУВАННЯ ТЕХНІЧНИХ РІШЕНЬ ЩОДО ПІДВИЩЕННЯ ЖИВУЧОСТІ АВТОМОБІЛЬНОЇ ТЕХНІКИ ЗБРОЙНИХ СИЛ УКРАЇНИ
}

\begin{abstract}
Анотація. В останні роки воєнно-технічна політика технічно-розвинутих країн відрізняється високою динамічністю, гнучкістю, сконцентрованістю на пріоритетних напрямках воєнно-технічного будівництва. Основним її завданням $є$ створення систем озброєння, що здатні за рахунок якісної переваги забезпечити успішне рішення національними збройними силами бойових завдань з можливістю нав'язування противнику в ході бойових дій вигідних для себе форм і способів воєнного протиборства. Бойові дії на Сході України вимагають постійного вдосконалення технічних характеристик зразків озброєння та військової техніки з метою якісної протидії кількісній перевазі збройним силам Російської Федерації та іншим формуванням з нетиповою організаційно-штатною структурою. Великі втрати зразків озброєння та військової техніки Збройних Сил України обумовлюють постійний пошук нових ефективних шляхів підвищення живучості зразків озброєння та військової техніки Збройних Сил України. В ході проведеного авторами дослідження розглянуто основні напрямки підвищення живучості зразків автомобільної техніки військового призначення. В ході проведеного авторами дослідження використані основні положення протимінної стійкості, теорії живучості та загальнонаукові методи аналізу та синтезу. За результатами проведеного дослідження авторами визначено, що основні напрямки підвищення живучості автомобільної техніки військового призначення направлені на: оптимізацію компонувальних схем; впровадження засобів посилення протимінної стійкості; різні види бронювання з використанням сучасних високоміцних матеріалів; впровадження матеріалів $і$ нових технологій, що забезпечують скритність; підвищення рухливості автомобіля. Реалізація зазначених напрямків підвищення живучості автомобільної техніки військового призначення дозволить зберегти життя особового складу та дозволить забезпечити виконання поставлених завдань.
\end{abstract}

Ключов і слов а : стандарти, спроможності, НАТО, Збройні Сили України, автомобільна техніка, живучість, протимінна стійкість.

\section{Вступ}

В останні роки воєнно-технічна політика технічно-розвинутих країн відрізняється високою динамічністю, гнучкістю, сконцентрованістю на пріоритетних напрямках воєнно-технічного будівництва.

Основним іiі завданням є створення систем озброєння, що здатні за рахунок якісної переваги забезпечити успішне рішення національними збройними силами бойових завдань 3 можливістю нав'язування противнику в ході бойових дій вигідних для себе форм і способів воєнного протиборства.

Разом 3 тим, бойові дії на Сході України вимагають постійного вдосконалення технічних характеристик зразків озброєння та військової техніки 3 метою якісної протидії кількісній перевазі збройним силам РФ та іншим формуванням з нетиповою організаційно-штатною структурою [1-3].

Враховуючи зазначене, метою зазначеної cmammi $є$ обгрунтування технічних рішень щодо підвищення живучості автомобільної техніки збройних сил України.

\section{Виклад основного матеріалу}

Істотне нарощування оперативних i бойових можливостей збройних сил провідних країн світу за рахунок їх оснащення високоефективними зразками озброєння та військової техніки (ОВТ) дозволяє досягати своїх політичних цілей силовим способом.

У період до 2030 року основні види та типи OВТ провідних країн світу будуть вдосконалюватися головним чином еволюційним шляхом, що не виключає при цьому можливості зростання їх окремих якісних характеристик в кілька разів.
Автомобільна техніка військового призначення (АТВП) відноситься до одного 3 найчисленніших видів озброєння військової і спеціальної техніки, що забезпечують мобільність військ армії будь-якої держави. Наприклад, тільки в збройних силах США легких по масі автомобілів військового призначення типу “Хаммер” налічується 200 тис. одиниць, в тому числі 160 тис. - в Сухопутних військах. Зразки АТВП широко застосовують не тільки для транспортування особового складу і військових вантажів, а й як базові шасі під монтаж різних видів озброєння і техніки, включаючи спеціальні в усіх видах і родах військ. Саме тому технічний рівень оснащення АТВП поряд 3 мобільністю частин і підрозділів, ефективністю функціонування систем їх матеріально технічного забезпечення, визначає бойовий потенціал військових формувань. Застосування АТВП в якості засобу мобільності різних артилерійських систем, зенітно-ракетних комплексів, засобів зв язку та інших видів озброєння і техніки дозволило значно підвищити маневреність і рухливість військ. Однак при цьому гостро постала проблема забезпечення захищеності від засобів ураження противника не тільки екіпажів, але також самого кошти рухливості. Тому однією з основних задач забезпечення бойової ефективності АТВП в арміях розвинених країн $є$ підвищення іiі живучості. Таким чином, перед конструкторами автомобілів постало завдання перетворити їх в високоефективні бронеавтомобілі, в кожному 3 яких будуть поєднуватися функції транспортного засобу і бойової машини підвищеної живучості.

Аналіз розвитку бронеавтомобілів [1-3] показує, що забезпечення їх живучості виробляється із застосуванням різноманітних технічних рішень. 
3 метою забезпечення захисту від ударної хвилі, від осколків мін і снарядів застосовується оптимізація компонувальною схеми автомобіля. вона передбачає розміщення екіпажу, основних вузлів i агрегатів машин в місцях, що обмежують вплив зазначених вище вражаючих факторів.

При цьому одним 3 пріоритетних напрямків $\epsilon$ реалізація принципу - чим менше мета, тим важче в неї потрапити. Цей принцип використовують всі виробники автомобілів. У класі бойових колісних машин зроблений акцент на легкі і середні автомобілі повною масою 6-7 т. Однак габарити агрегатів, обладнання та внутрішні обсяги не дозволяють по- вністю використовувати вищевказаний підхід. Тому конструктори намагаються оптимізувати габарити, максимально зменшити висоту машин, застосовувати схему “кліренс + внутрішній обсяг салону”.

Регульована підвіска дозволяє піднімати і опускати корпус інструмента в залежності від виконуваних завдань. Підвищення живучості автомобіля здійснюється за рахунок забезпечення його скритності. Скритність бронеавтомобіля здійснюється за рахунок застосування маскуючого фарбування (рис. 1), використання систем пуску димових (аерозольних) завіс, зниження помітності в радіодіапазоні, інфрачервоному і оптичному діапазонах.
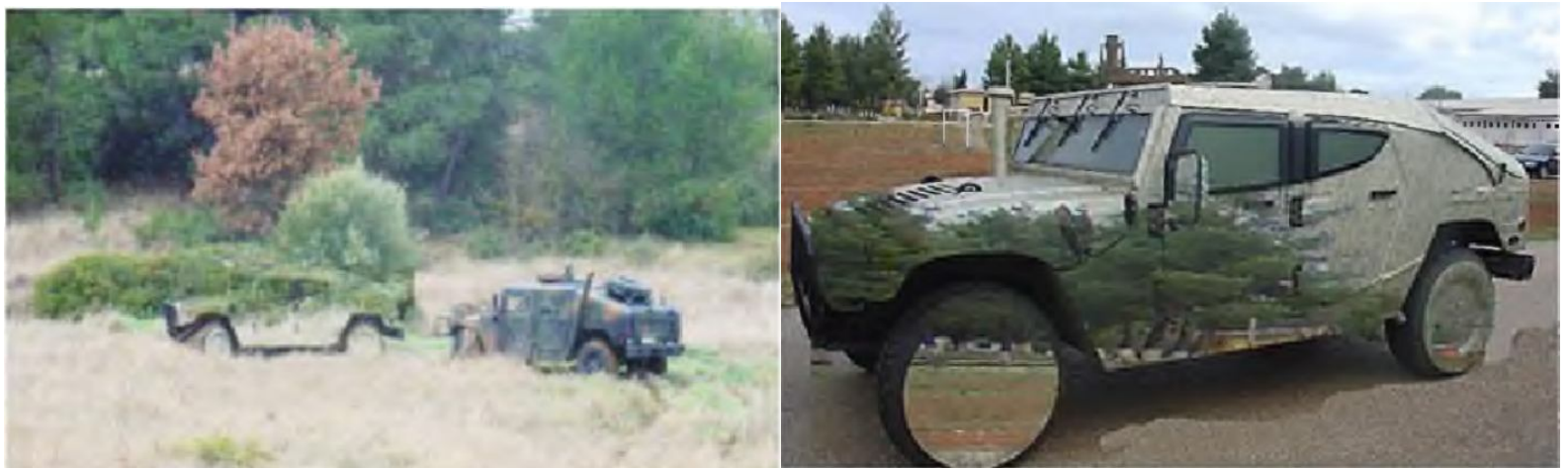

Рис. 1. Приклад використання маскуючого фарбування автомобілю

Досягнення малої помітності від засобів радіолокації наземних цілей досягається застосуванням радіо прозорих композитних матеріалів (керамічна або композитна броня). Зниження видимості вузлів і агрегатів з металу здійснюється їх екрануванням.

Скритність пересування бронеавтомобіля забезпечується застосуванням тягових електродвигунів, теплове випромінювання яких не перевищує 515\% від підводиться до них електроенергії, в той час як у двигуна внутрішнього згоряння розсіюється у вигляді теплового випромінювання до 70\% енергії згорає в ньому палива. Звук двигуна внутрішнього згоряння демаскує автомобіль, а електродвигуни можуть бути практично безшумними. Безшумна робота двигуна досягається також завдяки збалансованості деталей, максимально знижує вібрацію, крім цього застосовуються високоефективні системи охолодження випускних газів, системи комп'ютерного управління вентиляторами охолодження і турбіною надуву.

Застосування різних видів бронювання в значній мірі впливає на забезпечення живучості автомобіля. Сьогодні існують два основні варіанти забезпечення захисту від куль, осколків і кумулятивних боєприпасів. Перший - виконання броньовий конструкції з незмінним рівнем захисту при умови забезпечення високої стійкості. Прикладом може служити броньована конструкція німецького бронеавтомобіля "Боксер", яка забезпечує захист від 30-мм бронебійно-підкаліберних снарядів автоматичних гармат при масі машини 30 т. Другий - застосування базового рівня захисту 3 можливістю посилення броньовий конструкції в залежності від умов обстановки. Додаткова (навісна) захист встановлюється на деякій відстані від основного корпусу і виготовляється, як правило, з композиційних матеріалів.

Наприклад, корпус бронеавтомобіля VBCI виготовлений з алюмінієвої броні з накладками з броньованої сталі або титану, що забезпечують захист від 14,5-мм бронебійних куль або 25-мм бронебійних снарядів відповідно. Одним з конструктивних рішень $\epsilon$ застосування днища корпусу, що має F-образний перетин (рис. 2), що сприяє відображенню ударної хвилі або осколків. Підбір оптимальних кутів нахилу броньових листів дозволяє підвищити захист екіпажу від бокового обстрілу зі стрілецької зброї (рис. 3). Крім того, застосовується додаткове навісне бронювання з використанням різних екранів і протикумулятивних решіток.

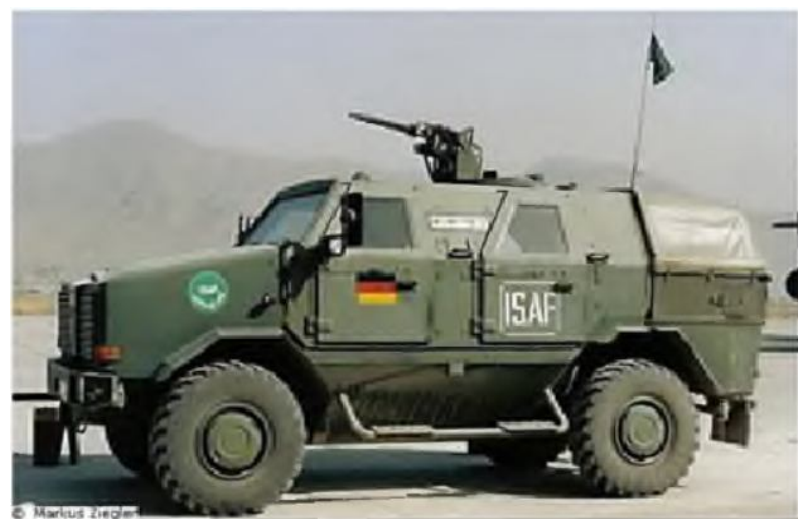

Рис. 2. Бронеавтомобіль “Дінго-2”

В армії США на більшості моделей автомобілів застосовується бронювання винесеного за базу автомобіля моторного відсіку, який на підрив бере на 
себе левову частку енергії вибуху і дозволяє протистояти легкому і важкому стрілецької зброї бойовиків, практично переважному в їх озброєнні.

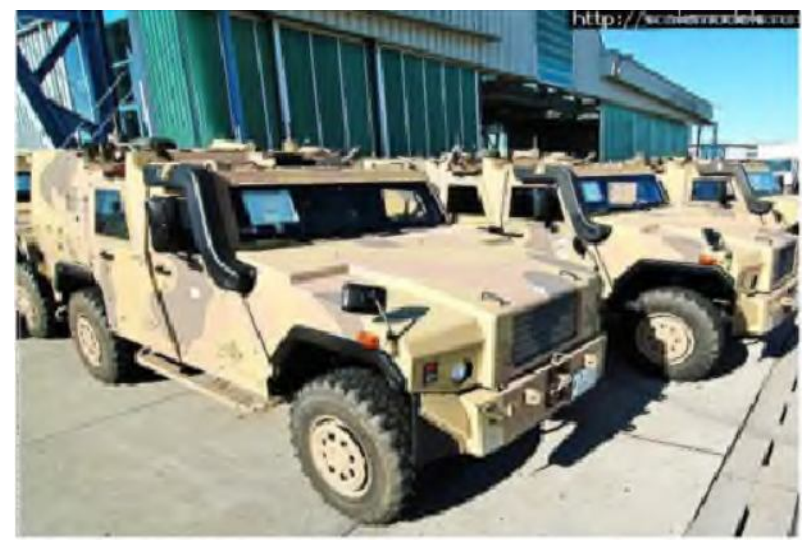

Рис. 3. Бронеавтомобіль “Ігл-4”

У збройних силах багатьох іноземних держав знайшли широке застосування нетрадиційні броньові матеріали (сталь замінюється керамікою, алюмінієм і армованими пластмасами), посилення броньовий захисту передньої і бічних частин корпусу керамічними плитками, бронювання судний водія i командира знизу, бронювання вітрових стекол, бронювання захисту днища кузова, двигуна, трансмісії, роздавальної коробки і паливного бака.

Для досягнення високої протимінної стійкості при конструюванні бронеавтомобілів широко застосовують такі рішення:

використання міцної кабіни-капсули; обладнання бойового відділення багатошаровим днищем;

розміщення зовнішніх панелей, що поглинають енергію вибуху; застосування додаткових захисних панелей на підлозі;

збільшення динамічного ходу коліс; конструктивне відділення сидінь від підлоги.

Кабіна-капсула при підриві на міні служить надійним захистом для екіпажу. Зміцнення не всієї машини, а тільки кабіни дозволило помітно знизити загальну масу автомобіля і забезпечити з великою ступенем ймовірності виживання особового складу.

Сидіння спеціальних конструкцій не мають жорсткого зв'язку з підлогою автомобіля і захищають від ураження опорно-руховий апарат людини.

Найпоширенішим варіантом $є$ кріплення сидінь до стелі корпусу автомобіля за допомогою гнучких кріплень. Обладнання автомобіля зовнішніми панелями забезпечує розсіювання енергії вибухових пристроїв. Використання перерахованих вище конструктивних рішень забезпечує виживання екіпажу при підриві на фугасні пристрої потужністю до 8 кг в тротиловому еквіваленті під колесом і 6 кг під днищем машини. На живучість автомобіля в певній мірі впливає його рухливість. Підвищення рухливості автомобіля дозволяє швидко і своєчасно вийти 3під вогню противника. Для цього на сучасних і розроблюваних зразках бронеавтомобілів простежуються тенденції застосування [1]:

гідромеханічних і електричних трансмісій;

гідропневматичних підвісок; більш потужних двигунів з турбокомпресорами iз змінною геометрією i електронними блоками управління режимом роботи двигуна;

протибуксовочних і антиблокувальних систем;

системи управління міжосьовими і міжколесними диференціалами;

електричних приводів коліс (рис. 4), модернізованих систем автоматичного регулювання тиску повітря в шинах, а також боєстійких шин.

На нових бронеавтомобілі зарубіжного виробництва використовується гідромеханічна трансмісія, що дозволяє на бронеавтомобілі з колісною формулою 8 × 8 за рахунок зміни різниці швидкостей обертання коліс на протилежних бортах зменшити радіус повороту до 8-10 м, на відміну від колишніх 25-30 м.

С дослідні зразки колісних машин з можливістю розвороту на місці. Однією з тенденцій є застосування гідропневматичною підвіски, забезпечує не тільки високі параметри підресорювання, а й можливість регулювання дорожнього просвіту і кутів крену машини для досягнення високої прохідності. Крім цього при високій ймовірності підриву бронеавтомобіля встановлюється максимальний просвіт, а при завантаженні в військово-транспортний літак він зменшується до мінімуму. Активно ведуться дослідно-конструкторські роботи по вдосконаленню автомобілів 3 гібридними (комбінованими) силовими установками. впровадження електромоторів в маточину кожного колеса і відсутність прямого зв'язку з двигуном дозволять зберегти рухливість в разі виходу 3 ладу одного з приводів. Це дає можливість машині самостійно вийти з-під вогню противника при підриві на міні або ураженні іншими видами зброї.

Для підвищення живучості та експлуатаційної надійності бронеавтомобіля широко застосовуються боєстійкі шини [4-7]. Їх диски оснащуються додатковими внутрішніми ободами 3 композиційних матеріалів, що забезпечує при пошкодженні або розриві шини рух машини по пересіченій місцевості зі швидкістю 20 км / год на відстань не більше 50 км (рис. 4, 5).

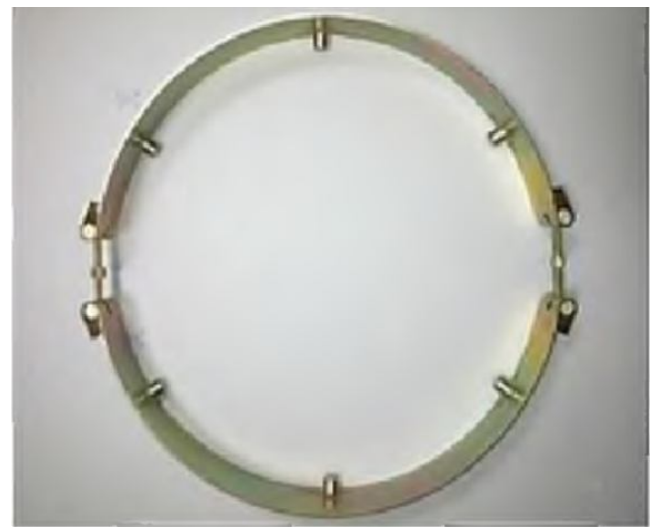

Рис. 4. Вставка безпеки

Перспективним напрямком розвитку кулестійких шин $\epsilon$ непневматичні шини (рис. 6). У таких конструкціях пневматична резинометалева оболонка замінена на конструкцію з полімерних матеріалів. Ці шини працюють без створення всередині них надлишкового тиску, що робить їх нечутливими до 
проколу. Крім того, шини подібної конструкції поглинають частину енергії при підриві на вибуховому пристрої. Однією з різновидів непневматичних шин $\epsilon$ шини NPT (Non pneumatic tire).

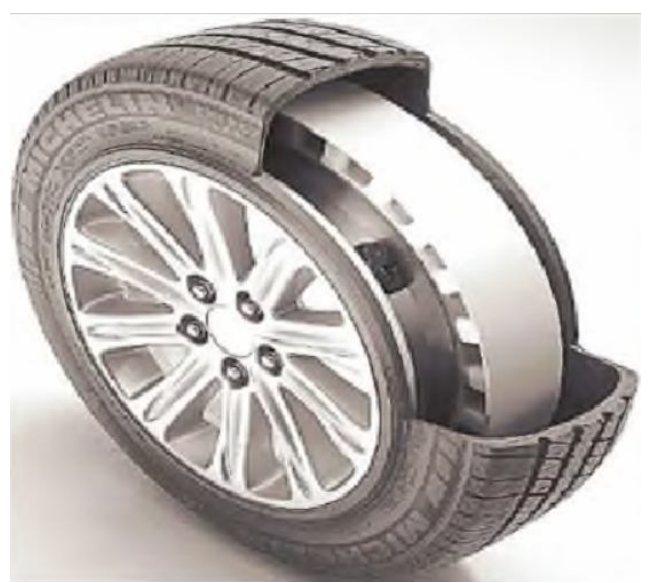

Pис. 5. Пневматична шина Michelin PAX з еластичної кільцевої вставкою

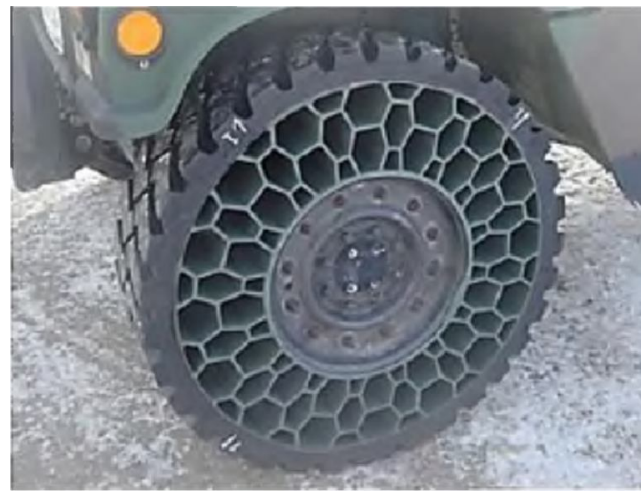

Рис. 6. Непневматичне колесо типу NPT

Шина має стільникову структуру і здатна виконувати свої функції при руйнуванні своєї структури до $30 \%$. Також вона не вимагає обслуговування протягом всього терміну служби.

Однак недоліком непневматичних шин $є$ неможливість їх використання на високих швидкостях через перегрів, підвищена гучність, менші демпфіруючі властивості, а також неможливість зміни тиску на грунт шляхом зміни тиску в шині.

В даний час приділяється достатня увага зниження маси автомобіля при збереженні рівня захисту 3 метою підвищення маневреності за рахунок розробки нових міцних легких матеріалів для бронювання. Крім того, в інтересах зниження вартості технічного обслуговування i ремонту, потреби в запасних частинах і скорочення часу на навчання особового складу ремонтних підрозділів конструктори ведуть розробку сімейств машин, що мають до $90 \%$ взаємозамінних вузлів і агрегатів.

Крім підвищення живучості автомобілів військового призначення ведуться науково-дослідні і дослідно конструкторські роботи із забезпечення недопущення виведення 3 ладу водіїв і екіпажів. У цій області виділилося і швидкими темпами розвивається напрямок по створення роботизованих машин 3 функцією штучного інтелекту.

\section{Висновки}

Таким чином, проведений у статті аналіз показав, що технічні рішення що застосовуються в арміях провідних країн світу дозволяють забезпечити ефективну захист автомобіля від різних видів зброї, підвищити його живучість, є загальними і можуть бути розділені на кілька основних напрямків:

1) оптимізачія компонувальних схем:

застосування модульних конструкцій на базі уніфікованого шасі в залежності від вирішуваних завдань;

зменшення габаритних параметрів автомобіля;

2) впровадження засобів посилення протимінної стійкості:

застосування регульованого кліренсу в сукупності з F-образним, зі збільшеною стійкістю (багатошаровим) днищем;

застосування броньованої капсули;

застосування різних панелей, що поглинають енергію вибуху;

застосування сидінь, які не мають жорсткого зв'язку з підлогою;

3) різні види бронювання з використанням сучасних високоміцних матеріалів:

застосування нетрадиційних броньових матеріалів;

застосування зварного корпусу машини, що складається 3 окремих броньових листів різної товщини;

застосування оптимальних кутів нахилу броньових листів;

застосування додаткового навісного бронювання 3 використанням різних екранів і противокумулятивних решіток;

застосування броньовий захисту передньої і бічних частин корпусу, посиленою керамічними плитками;

застосування броньовий захисту днища кузова, двигуна, трансмісії, роздавальної

коробки і паливного бака;

застосування броньованих вітрових стекол;

застосування броньованого моторного відсіку, винесеного за базу автомобіля;

4) впровадження матеріалів $i$ нових технологій, щчо забезпечують скритність:

застосування маскує фарбування;

застосування різних систем пуску димових (аерозольних) завіс;

зниження помітності в радіо-, ІЧ-і оптичному діапазонах шляхом установки

захисних екранів, захисних фарб, спеціальних панелей і т. д .;

зниження шумності роботи двигуна;

застосування високоефективної системи охолодження випускних газів,

комп'ютерного управління вентиляторами охолодження і турбіною наддуву;

5) підвищення рухливості автомобіля шляхом застосування:

гідромеханічних і електромеханічних трансмісій; гідропневматичних підвісок; 
більш потужних двигунів з турбокомпресорами iз змінною геометрією i електронними блоками управління режимом роботи двигуна;

протибуксовочних і антиблокувальних систем, систем управління міжосьовими і міжколесними диференціалами;

гібридних силових установок, електричних приводів коліс, модернізованих систем автоматичного регулювання тиску повітря в шинах, а також боєстійких шин.

Необхідно відзначити, що в багатьох країнах 3 метою збереження життя водіїв і екіпажів виділилося перспективний напрямок - розробка дистанційно керованих машин, а також роботизованих машин 3 функцією штучного інтелекту.

Таким чином, необхідність підвищення живучості АТВП обумовлена збільшенням її кількості в військах як засіб рухливості озброєння, що наблизило АТВП до місць ведення активних бойових дій і підвищило ймовірність ураження зброєю різних видів. Аналіз технічних рішень щодо підвищення живучо- сті АТВП, застосовуваних в арміях іноземних держав, показує, що забезпечення ефективної захисту автомобіля від різних видів зброї і підвищення його живучості проводиться по такими основними напрямками: оптимізація компонувальних схем АТВП, впровадження засобів посилення протимінної стійкості, застосування різних видів бронювання з використанням сучасних високоміцних матеріалів, підвищення скритності і рухливості АТВП.

Виділені напрямки є основними і загальними для більшості армій передових держав, що займаються підвищенням живучості АТВП.

Реалізація зазначений напрямків підвищення живучості автомобільної техніки військового призначення дозволить зберегти життя особового складу та дозволить забезпечити виконання поставлених завдань.

Напрямком подальших досліджень слід вважати розробку методики підвищення протимінної стійкості автомобільної техніки військового призначення.

\title{
СПИСОК ЛІТЕРАТУРИ
}

1. Купріненко А. Н., Голуб В. А. Синтез вариантов проектных гипотез технического облика перспективных типов боевых бронированных машин // Військово-технічний збірник / Академія Сухопутних військ. № 2(9). Львів : АСВ, 2013. C. $36-42$.

2. Global armoured vehicles market report 2016/ URL: Режим доступу: http://www.defenceiq.com/amouredvehicles/articles/summary-of-global-armoured-vehicle-market-report-2.

3. Купріненко О. М. Обгрунтування принципів формування перспективних типів бойових броньованих машин // Системи озброєння і військова техніка. 2012. № 4(32). С. 40-46.

4. Купріненко А. Н., Голуб В. А. Выбор рационального варианта проектной гипотезы технического облика перспективных типов боевых бронированных машин // Системи озброєння і військова техніка. 2013. № 3(35). C. 24-28.

5. Бісик С. П., Бойко Г. О. Деякі дані сучасного стану й тенденцій розвитку колісних бойових броньованих машин // Озброєння та військова техніка : щокв. наук.-техн. журн. / ЦНДІ ОВТ ЗСУ. 2014. № 3(3). С. $20-24$. DOI: https://doi.org/10.34169/2414-0651.2014.3(3).15-19.

6. Кузнецов, Ю. Основные направления развития боевых колесных машин зарубежных стран // Зарубеж. воен. обозрение. - 2013. - № 4. - С. 46-51.

7. Литвиненко А. В., Ткачук Н. А., Литвин Б. Я., Шейко А. И. Общий подход к проектно-технологическому обеспечению защищенности бронекорпусов транспортных средств специального назначения // Механіка та машинобудування. 2012. № 2. С. 221-229.

Надійшла (received) 08.01.2020

Прийнята до друку (accepted for publication) 12.02.2020

\section{Substantiation of technical solutions for increasing living Car technology of the armed forces of Ukraine}

\author{
M. Kovba, V. Riy
}

Abstract. In recent years, the military-technical policy of technically developed countries has been highly dynamic, flexible, and concentrated on the priority areas of military-technical construction. Its main task is the creation of weapons systems that, due to their qualitative advantage, are capable of ensuring the successful fulfillment of combat missions by the national armed forces with the possibility of imposing on the enemy forms of military confrontation that are advantageous for themselves in the course of hostilities. Fighting in the east of Ukraine requires continuous improvement of the technical characteristics of weapons and military equipment in order to qualitatively counter the numerical superiority of the armed forces of the Russian Federation and other forces with an atypical organizational and staff structure. Large losses of weapons and military equipment of the Armed Forces of Ukraine are caused by the constant search for new effective ways to increase the survivability of weapons and military equipment of the Armed Forces of Ukraine. In the course of the study, the authors examined the main directions of increasing the survivability of military vehicles. In the course of the study, the authors used the main provisions of mine resistance, survivability theory and general scientific methods of analysis and synthesis. According to the results of the study, the authors determined that the main directions of increasing the survivability of military vehicles are aimed at: optimizing layout schemes; the introduction of means to strengthen mine resistance; different types of booking using modern high-strength materials; the introduction of materials and new technologies that provide stealth; increase vehicle mobility. The implementation of these directions of increasing the survivability of military vehicles will save the lives of personnel and will ensure the fulfillment of tasks.

Keywords: standards, capabilities, NATO, Armed Forces of Ukraine, automotive equipment, survivability, mine resistance. 